\title{
Grey Matters: The 'Constructed' and 'Unconstructed' Outdoor Formation For Young Adults As An Extension of the Dwelling
}

\author{
Gri Madde: Genç Yetişkinler İçin Konutun Uzantısı Olarak \\ Kurgulanmış ve Kurgulanmamış Açık Alan Oluşumları
}

\author{
Sedef ÖZÇELIK GÜNEY,' Yurdanur DÜLGEROĞLU YÜKSEL²
}

\section{ABSTRACT}

Due to the dense population patterns in the urban environment, residential outdoor usage need have shifted from planned or constructed semiprivate/semipublic and open/semiopen spaces ("gray matters"/GM) to unconstructed outdoor spaces. This is related to demographic characteristics, daily living cultures, and the physical features of the space. This study aims to explore educated young adults' perception, usage, and social interaction patterns for Grey Matters formations. The methodology is conducted reflecting the first 3 steps of a planned 6-step research project. Quantitative and qualitative data obtained through questionnaires and in-depth interviews with 49 young adults were analyzed. The study shows that the young adults need the outdoors at least for "taking take a breath." Nevertheless, the grey matters are not always the architectural "text book examples." They are sometimes generated by coincidence but perceived to be the most prominent ones or the contrary. Young adults, aged between 23 and 37 with higher education degrees, specifically those living on the metro line routes on the Istanbul European side, are focus. In the dense urban area, young adults prefer to use some particular residential spots as if they were their own backyard, lawn, or porch. They read, study, exercise, interact, conduct meetings, drink coffee/ tea, and smoke. They develop an "ownership" despite the spaces being "no man's lands" regarding the urban definitions.

Keywords: Grey matters (GM); residential areas; urban context; young adults.

Yoğun konut dokusu içinde açık alan kullanımı planlanmış (kurgulanmış) yarı-özel/yarı-kamusal ve yarı-açık/açık alanlardan ('gri madde' GM) kurgulanmamış açık alanlara kaymaktadır. Bu konu demografik yapı, gündelik yaşam kültürü ve mekanın fiziksel özellikleriyle ilişkilidir. Çalışma; eğitimli genç yetişkinler için Gri Madde oluşumunu algılama, kullanma ve sosyal etkileşim kalıpları açısından incelemeyi amaçlamaktadır.Bütünde 6 adımdan oluşan araştırma temellendirilmiş kuram metodu ile araştırılmaktadır. Makale araştırmanın ilk 3 adımında nicel/ nitel stratejilerle 49 katılımc ile yapılan anket ve derinlemesine görüşmelerden elde edilen bulguları kapsamaktadır. Sonuçlar, genç yetişkinlerin en azından 'bir nefes almak' amacıla konut çevresinde gri maddeye ihtiyaç duyduklarını göstermektedir. Buna karşın tüm sahada tespit edilen gri madde örnekleri mimari tasarım kitaplarındaki teorik yapıyla tam olarak örtüşmemektedir. Bazı durumlarda tesadüfen oluşmuş bazı alanlar çok yoğun kullanılmakta ya da tam tersi gerçekleşmektedir. Üniversite mezunu 23-37 yaş aralığında; İstanbul Avrupa yakası metro güzergahı üzerinde yaşayan genç yetişkinler örnekleme oluşturmak üzere dikkate alınmıştır. Söz konusu alandaki yoğun doku içinde bu genç yetişkinlerin gri maddeyi kendi arka-ön bahçeleri ya da terasları gibi kullandıkları görülmektedir. Bu alanlarda okumakta, çalışmakta; sporyapmakta, sosyalleşmekte; hatta işle ilgili toplanmakta, çay-kahve-sigara içmektedirler. Kimsenin olmayan bu alanlara ilişkin bir sahiplenme geliştirmektedirler.

Anahtar sözcükler: Gri madde (GM); konut alanları; kentsel doku; genç yetişkinler. 


\section{Introduction}

Even though semi-private/semi-public, semi-open/ open residential spaces are defined with respect to the architectural theories, the formulation in the urban area shifts from by the book definitions to formed by coincidence. The transformation of such unconstructed spaces into open-air extensions of the dwellings - Gehl called as soft edges ${ }^{1}$ vary with respect to demography, daily living culture of dwellers and characteristics of the most available/prefered outdoor space. These spaces are called as grey matters in this study. The name refers to the terminology in biology which is defined as the greyish tissue of the brain and spinal cord, containing nerve cell bodies, dendrites, and bare axons. This element of brain enables electrical impulse exchange between brain cells. So it works as a space to provide connections for different activities of brain (Oxford References). In the metaphorical senses, the semi-private/semi-public, semi-open/open spaces in the housing areas that provide social interaction platforms and act coherent to the grey matter element in the brain. ${ }^{2}$

In this frame the research question: Do the demographics, daily living culture and available GM characteristics affect the constructed and unconstructed GM formation in terms of perception, usage and support the social life for young adults?

The public and private residential open space definitions refer to certain claims of the owners and limitations of the users; ${ }^{3}$ as such one particular terrace attached to a dwelling belongs to the household of that particular property or a public space is accessible on the regular basis. ${ }^{4}$ It is evident that the residents may develop a stronger sense of identity for places in the secondary territories (less exclusive spaces than the private domains). They represent a public availability and control at a certain level. They are the links between private and public domain $s^{5}$ and can be regarded as buffer zones. The thresholds dissepear through buffer zones where thresholds point out strict lines between different domains. For instance garden walls divide the open space in the housing area into two parts: semi-private and public. In such cases buffer zones offer preparation spaces in terms of space hierarchies.

In the urban context, the hierarchial order of private domain in the residential areas formulate permeable and semi-permeable articulations. The upper yellow line displays the passage line of the households from their dwelling to the public space. Semi-private and semi-public spaces are in an order and create gradual privacy levels. However; on the current urban structure the strict saperation of semi-private and semi-public are not detected any-

1 Gehl, 1986, p. 90.

2 Ozcelik-Guney, 2014, p. 3.

3 Lopes et al., 2012, p. 11.
4 Altman and Chemers, 1980 , p. $120-$ 153.

5 Altman and Chemers, 1980, p. 131. more. Those two semi-spaces blend and denote a common ground. The bottom yellow line represents the daily passage practice of an household. It becomes difficult to distinguish semi-private and semi-public spheres. Thus the grey matter circle attached to the dwelling core stands for this blended common ground (Fig. 1).

Even though the issue has been tackled under various terminologies such as; secondary territories, ${ }^{6}$ threshold, ${ }^{7}$ soft edges, ${ }^{8}$ territorial depth ${ }^{9}$ and collective space ${ }^{10}$ in literature; Geh ${ }^{11}$ relates this to the transition area phenomenon with the idea of liveliness. He explains that the duration of various activities in the residential open spaces provide life; where life is defined as persons being present in one particular area. Every GM area providing a certain level of liveliness is not necessarily designed by the urban administrations or other authorities. On the contrary; these spaces can be unconstructed residential out-door spots claimed by the residents.

Due to the recent work trends, young adults prefer to live in the city centre. Specifically in the Istanbul metropolitan area, this tendency goes even higher considering heavy traffic and long distances being travelled. Moreover; for the young adults the family responsibilities are relatively less and central spaces where social life is more accesible is highly prefered. The struggle to juggle changing job opportunities with localising lives is the major issue. ${ }^{12}$

The GM areas are mostly perceived as the out-door extensions of the dwellings since most houses in the central locations lack proper open/semi-open private spaces such as balconies, terraces or gardens. The concept grey matters undertake these out-door extensions. They are catogorised as constructed and unconstructed GM areas in this paper. In some cases; even if there are designed GM areas available in the neighbourhood, young adults prefer to use a space formed without designing (mentioned as by coincidence above). As a reference to Gouldner, ${ }^{13}$ the new middle class prefers some particular GM areas more than the others due to their local social status ${ }^{14}$ where the term refers to the preferences due to trends and life-style in people's local areas. Even though the trigger for out-door usage is physical necessities, the motivations for the GM choices are more psycological or even a sort of fashion. So the two main parameters; the dweller and the physical setting data are related with (1) perception, (2) usage, and (3) supportive role of GM for social interaction.

In this study demography adresses the age within 2337 (early phase/ 23-27, middle phase/ 28-32, late phase/

\footnotetext{
Altman and Chemers, 1980, p. 131. ${ }^{11}$ Gehl, 1986, p. 92.

Rapoport, 1969, p. 80.

Gehl, 1986, p. 90.

${ }^{12}$ Knorr-Siedow, 2008, p. 321.

13 Gouldner, 1979, p. 117.

9 Habraken, 1998, p. 137.
}

${ }^{10}$ Scheerlinck, 2012, p. 5. 


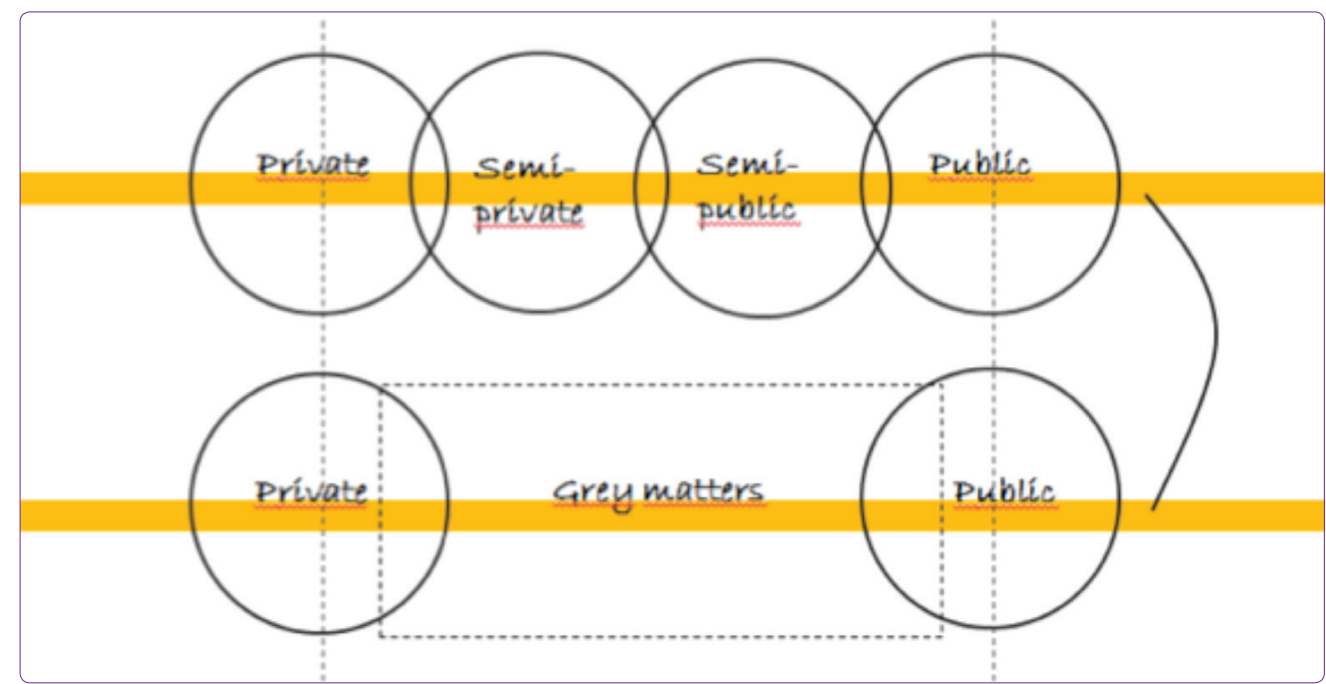

Figure 1. Formulation of Grey Matters (GM) in the urban context.

33-37), gender and marital status of young adults. For instance in the early age phase, the apartments are shared mostly with family members or friends so private conversations take place in the GM areas. Married couples' GM preferences are different than the single people. Having children is a major game changer ${ }^{15}$ since young adults use GM areas with respect to children's playground demands.

Daily living culture notion refers to the individual preferences, life-style tendencies, and urban life patterns as Thorkild states. ${ }^{16}$ In this case, the perception of GM is prominent and strongly related to the personal background including the socio-economic status, being raised in the city or rural areas, and the culture. Moreover, the religious beliefs, conservative tendencies and the professions are the components of the daily living cultures.

Physical features of GM areas stand for the specific characteristics of that particular GM. The physical environmental conditions as well as the unique features such as sea-front location, sea-view, protective formation from unplesant weather conditions or easy-to-access position are the components of the physical features.

First this paper explains the grey matter phenomena then describes constructed and unconstructed GM notions. Then the analysis of quantitative and qualitative research strategies are displayed with respect to grounded theory approach. Descriptive statistics culminated by questionaires make reference to the interpretative qualitative findings of 49 in-depth open-ended interviews.

\section{Constructed Gm Areas: Designed By Professionals}

The constructed GM is defined as open-semi/open, semi-private/semi-public residential spaces which are de-

\footnotetext{
15 Stegman, 1969, p. 27; Kim et al., 2005, p. 1623; Karsten, 2007, p. 83-87.

16 Thorkild, 2006, p. 111.
}

signed by professional means for common outdoor activities. In general, they are courtyards, small gardens, playgrounds, terraces, porches and local parks. These spaces are specifically planned considering out-door recreation (seating, coherent material with the out-door usage, urban furniture, shading and microclimates). ${ }^{17}$ Designed space provide a platform to explore how space can be used, or how architectural and urban space could create events. ${ }^{18}$ The event notion is built by Bernard Tschumi who claims that every space creates a potential for an event and every architecture is created with a programme. ${ }^{19}$

A varity of design methodologies for the built environments for common purposes are present ${ }^{20}$ in the constructed GM areas. Carr et al. establisha connection between space and its users via definition of five main terms: comfort, relaxation, passive and active engagement, and discovery. ${ }^{21}$ Montgomery adresses three basic features for successful urban areas: activity, image and form. ${ }^{22}$ Whyte founded a non-profit organization The Project for Public Spaces $^{23}$ which serves for a rather large field including public spaces with four main qualities; access and linkages; uses and activities; comfort and image; and sociability.

\section{Unconstructed GM Areas: Formed By Coincidence}

The unconstructed GM areas address spaces that are originally designed other usages (passage, serving food/ drinks for commercial purposes e.g. semi-open/open spaces of local cafe/bar/restaurants on the sidewalks, kiosks, public stairs). Such spaces undertake the roles of shared areas in the housing settlements and serve as interaction platforms for young adults living in the same neighbour-

\footnotetext{
17 Lopes et al., 2012, p. 14.

18 Livesey, 2007, p. 14

1998, p. 93-116; Whyte, 1980.

${ }^{19}$ Tschumi, 1983, p. 6.

${ }^{21}$ Carr et al., 1992, p. 46

22 Montgomery, 1998, p. 93-116.

${ }^{20}$ Carr et al., 1992, p. 46; Montgomery, ${ }^{23}$ Whyte, 1980.
} 
hood. Gehl ${ }^{24}$ describes the public space as the designed or natural open spaces around every building. The distinction between the public or private ownership is neglected in this study. So the spaces between buildings such as sidewalks or waterfronts and urban gardens ${ }^{25}$ as well as other GM forms are considered.

Jencks puts forward the term informality in design adressing the notions of being uncertain and making use of the possibilities. ${ }^{26}$ Lopes et al. imply a public character of social and civic functions; including the so-called semipublic spaces, such as cafés, book stores, bars, and etc. ${ }^{27}$ Soft possession is observed in the unconstructed GM areas referring to the connection that the user builds with a place of non-private domain. It is a sort of sense of belonging where the meanings create a certain level of attachment. ${ }^{28}$ So the particular space is used as if it belongs to those who use them. The GM area stands for the ongoing act of occupation that fixes the actual extent of the claim. ${ }^{29}$ The users can only have a claim on the shared space only if they spend time in it.

\section{The Young Adults}

The presentation of the self may alter for the changing angagements in living. ${ }^{30}$ So the place is perceived as a sense of belonging; and the information about where an individual lives can be connected to the social identity. According to Bourdieu; ${ }^{31}$ tastes and choices refer to education and class.

The new-life-style-group consisting of relevantly young professionals find traditional house forms insufficient and expensive. Some literature defines the educated young adults as the internship generation that prefer dwelling locations due to changing work opportunities. ${ }^{32}$ In the recent years many internships take from 6 months to 2 years after the undergraduate studies are finished. Young people move to other towns for training. So, the residential preferences and social interactions trace the uncertain career paths where young adults intend to socialise in an unfamiliar city. In such cases interaction around the housing takes important roles in young adults' lives where they try to orientate in the changing life settings.

Even though various studies state different categorisations for the age of young adults ${ }^{33}$ in different cultures. The avarage age for completing undergraduate studies, avarage recruitment age, marriage and other life engagements point 23-37 in Turkey. So the age of 23 is taken as the threshold for being a young adult. After the mid-

\footnotetext{
${ }^{24} \mathrm{Gehl}, 1987$.

${ }^{25}$ Francis, 2011, p. 432.

${ }^{26}$ Jencks, 1993.

27 Lopes et al., 2012, p. 13.

${ }^{28}$ Lopes et al., 2012, p. 15.

${ }^{29}$ Habraken, 2000, p. 130.
}

\footnotetext{
${ }^{30}$ Giddens, 1991, p. 189.

${ }^{31}$ Bourdieu, 1989, p. 14.

${ }^{32}$ Knorr-Siedow, 2008, p. 321.

${ }^{33}$ Knorr-Siedow, 2008, p. 319; Berngruber, 2015, p. 1275; GormanMurray, 2015, p. 422.
}

thirties family responsibilies increase and dwelling preferences tend to change. In the later years in a person's life; sub-urban living or low-density housing are prefered. Long distance travels to city centre are traded with larger dwellings, school opportunities and housing quality. ${ }^{34}$

\section{Approach and Methodology}

The research is based on the grounded theory approach. ${ }^{35}$ This approach provides new insights in the cases that the social reality is difficult to define with other theories. ${ }^{36}$ Due to the specifics of the study field; instead of seeking for the text-book definitions and testing hypothesis stated in previous literature, the development characteristics are deduced regarding the data obtained. So the constructed/unconstructed GM area types became the matters of exploration due to the data colected from the field. Noting that; grounded theory approach is a systematised qualitative research technique that develops the theory upon phenomena through hypo-deductive methods. Under this approach; qualitative and quantitative tactics are compiled. The main point is to build a new theory offering a very flexible set of research. ${ }^{37}$ The reseach design consists of three main steps. In the first step the most prominent GM areas that the participants use are asked in short telephone conversations. These spaces are observed and field notes are taken. Questionaires are completed with 49 participants and descriptive statistics analysis are completed on SPSS digital tool in the second step. In the third step, in-depth interviews are conducted in open-ended, semi-structured forms with the same sample.

Every questionaire took about 15 minutes and the interviews took longer, 45-90 min. each. During the interviews the differences between constructed and unconstructed $\mathrm{GM}$ areas are stressed. Moreover, the impression that $\mathrm{GM}$ areas create for the participants and their daily living routines are explored. The approach is developed to make meaning of the social world within its unique cultural context in the axes of commentary paradigm. ${ }^{38}$

\section{Sample}

Istanbul is the largest city in Turkey with a population of approximately 14 millions according to the official updates. Global service industry is developed related to the high industrial production which bears busy sea/air/land ports driving finance and trading. So the city also draws national/ international immigration, especially the young adults. Istanbul has an attractive image for job opportunities. The main transportation routes on the European side of the city has developed in the last decade where the underground

\footnotetext{
${ }^{34}$ Stegman, 1969, Brown, 1975; Kim, ${ }^{37}$ Corbin and Strauss, 1990, p. 419. 2006.

${ }^{35}$ Strauss \& Glaser, 1967, p. 23.

${ }^{36}$ Gençoğlu, 2014, p. 683.
} 


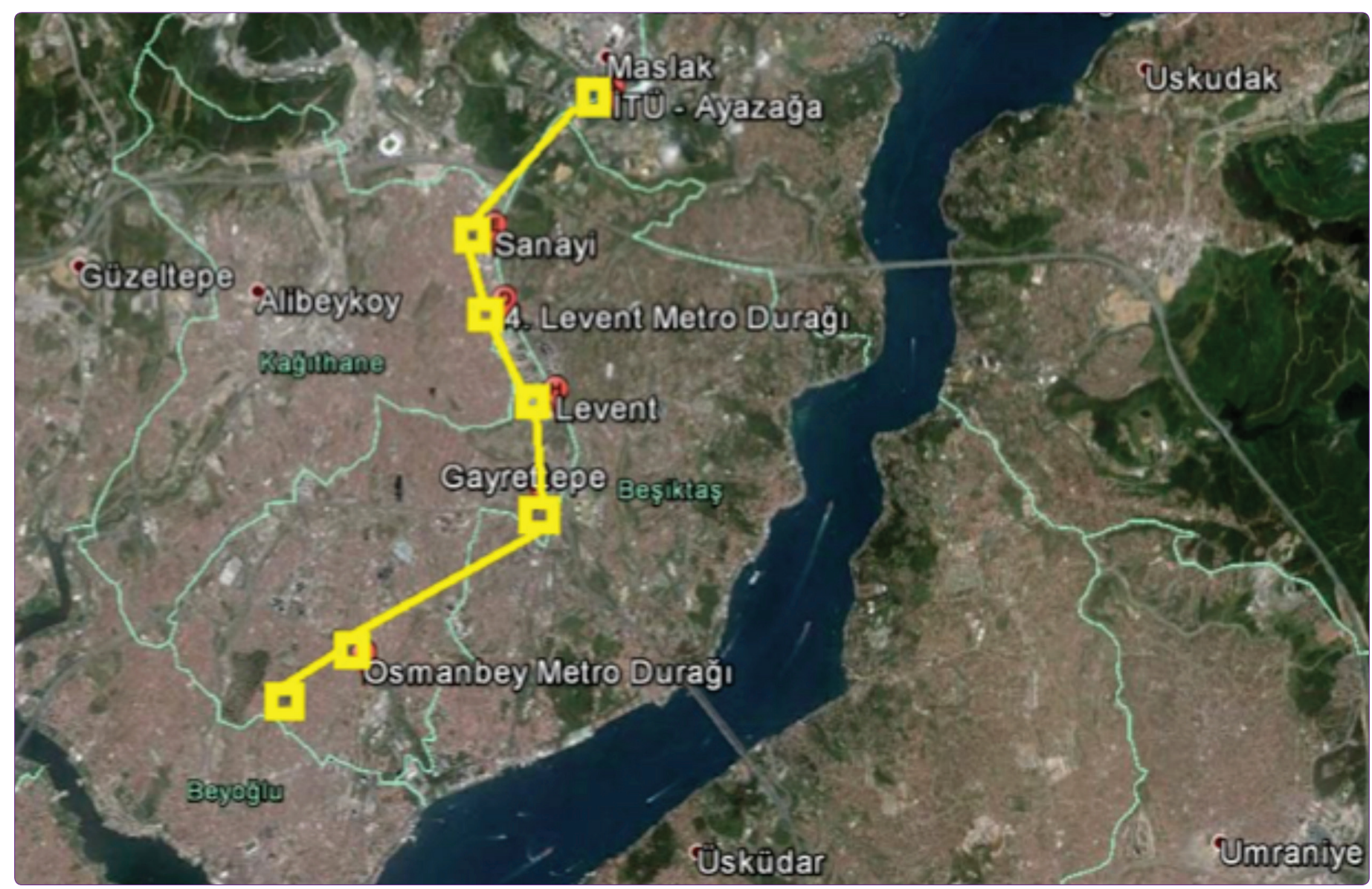

Figure 2. The underground route used for the sampling, Source: Google Maps.

line is extended from the financial centre - Maslak (Şişli/ Sarıyer), all the way to Beşiktaş and Şişli districts, the cultural and historical centre Beyoğlu and even further on both ways (Fig. 2). With the transportation the quarters that had lost their importance have regained respect again. ${ }^{39}$

Due to the recent residential trends in the city, a filtration in the universe of research is conducted by layered random sampling: (1) Age (2) Location (3) Education - undergraduate degree minimum. The universe addresses a very large number of individuals. So the study is restricted to four main districts: Beyoğlu, Şişli, Beşiktaş, Sarıyer (Table 1). The first trial by ringing door bells randomly was unsuccessful. The households would not answer unless they were expecting somebody due to safety reasons. In the second trial, adresses of the possible sample were obtained from various networks; referring to diverse quarters to reach diverse GM area types. A total of 56 young adults were subjected to research steps 2 and 3 . Only 49 of the whole questionaires and interviews were eligible. 13-14 subjects participated from every district in order to balance the dispersion of the sample.

\footnotetext{
${ }^{39}$ Oztel-Agsakalli and Zeren-Gulersoy, 2015, p. 86; Yardım and Hacihasanoglu; 2015, p. 47.
}

\section{Findings}

The data is analysed due to GM area preferences and reasons behind these preferences as mentioned above. Especially tendencies towards GM areas reflect individual insights about the young adults living in the city centre with career objectives. They put forward the new urban living practices and give hints to the designers about the social platforms that will be demanded in the future. They are reviewed thoroghly as the following:

- Perception of GM areas: The areas named as GM vary in character with respect to the memories, feelings and understanding of each individual due their background (demography) and daily living cultures.

- Usage of GM areas: There are 2 types of activities; (1) occurs mostly without interaction - exercising, dog-walking, smoking, (2) sociable usage - refers to spending time in the GM with open-to-social-interaction manners such as greeting, short conversations, chatting, making friends and gatherings.

- Supportive role of GM areas for social interaction: Due to the perception and usage tendencies; soft posession and familiarity are prominently built in GM areas. As the frequent usage occurs, interaction possibili- 
Table 1. The districts and quarters within for the sample

\begin{tabular}{lllll}
\hline Districts & Beyoğlu & Şişli & Beşiktaş & Şişli/ Sarıyer \\
\hline Quarters & Cihangir & Teşvikiye & Yıldız & Maslak (Dereiçi) \\
& Firuzağa & Feriköy & Mecidiye & \\
& Gümüşsuyu & Osmanbey & Cihannuma & \\
& Bereketzade (Galata) & Bozkurt & Sinanpaşa & \\
& Ömeravni (Fındıklı, Setüstü) & & Türkali & \\
& & Muradiye & \\
& & Vişnezade & \\
& & Dikilitaş & \\
& & Balmumcu & Abbasağa \\
\hline
\end{tabular}

ties increase, they provide stronger neighbourhood bonds, senses of identity and belonging (Table 2).

With respect to the data, the preferred GM areas are categorised in terms of typologies (constructed GM and unconstructed GM). Table 3 refers to the available GM area types and the preferences of sample regarding this

Table 2. The interrelations among GM parameters

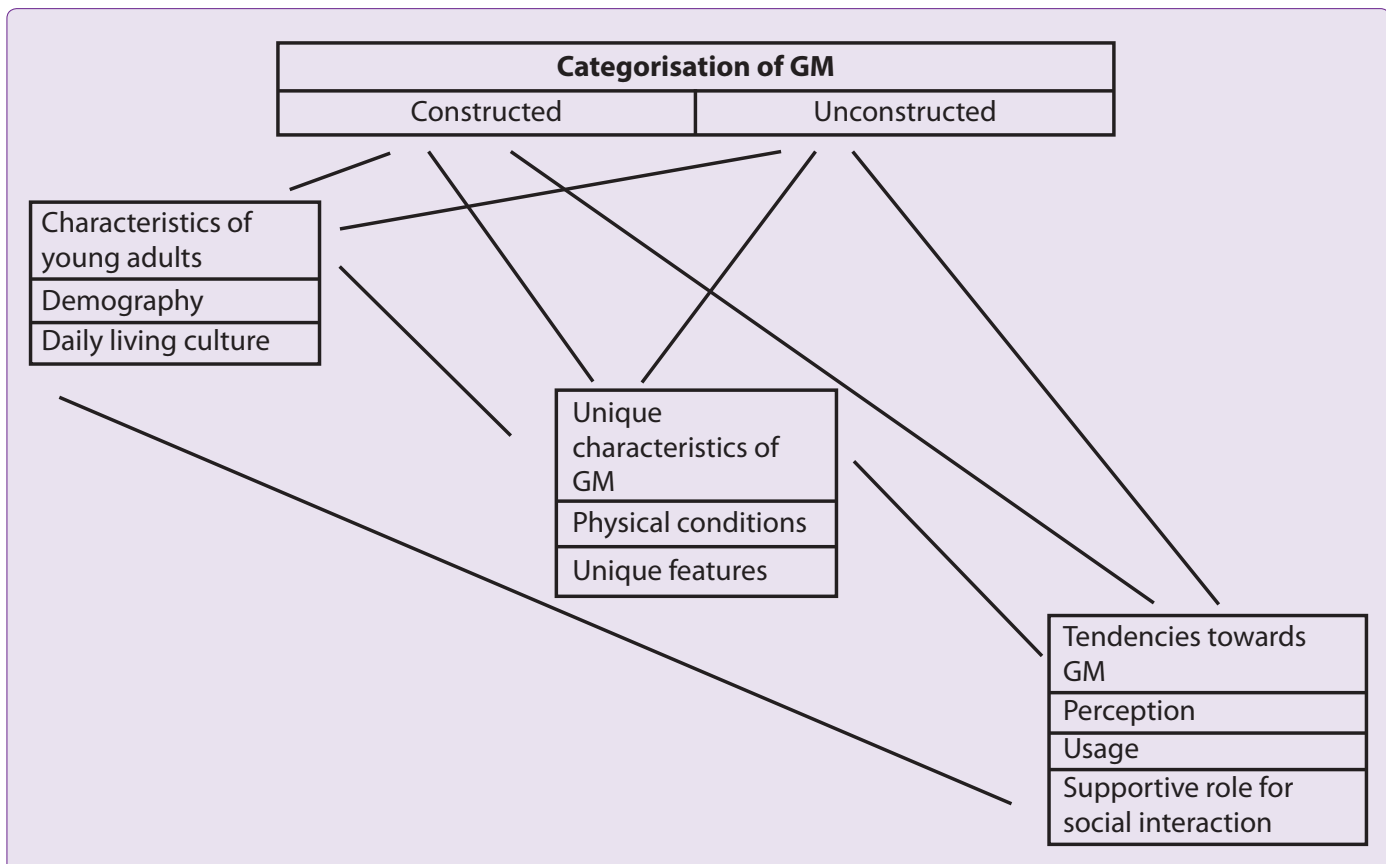

Table 3. The dispersion of prefered GM typologies within the sample and their assumed categories

\begin{tabular}{ccccc}
\hline & \multicolumn{4}{c}{ Categorisation of GM } \\
\cline { 2 - 4 } & Constructed & $\%$ & Unconstructed & $\%$ \\
\hline Preferred GM type & Park & 26.5 & Café & 34.7 \\
& Courtyard/garden & 10.2 & Café/park & 18.4 \\
Terrace/porch & 8.2 & Sidewalks & 2.0 \\
Total & 44.9 & Total & 55.1 \\
Total & & & 100 \\
\hline
\end{tabular}


categorisation. The table shows that more than half of the sample prefers unconstructed GM areas.

For further analysis, it is crucial to study the sample. The descriptive analysis of the sample displays a fair dispersion within the age phases; the early phase between 23-27 constitutes one third, and the oldest sample is represented by nearly $45 \%$. Gender dispersion is $41 \%$ male and $59 \%$ female. The level of education amongst the subjects are almost $82 \%$ with a Bachelor, $12 \%$ with Masters and $6 \%$ with $\mathrm{PhD}$ degrees. Almost the entire sample completed their studies (98\%) and the entire participants are continuing their professional lives. The professions are quite diverse: administration/economics, communications, teaching, architecture, engineering, social sciences, law and arts. The profession tends to be important due to the work patterns linked with GM area usage. More than half of the sample are single individuals (57\%) and more than one third is married. The majority lives with a spouse or children. Single living pattern is also prominent with a quarter of the entire sample. Income level of the sample diplays that the majority earns around 1000-1500 euros per month.

\section{Demography}

One of the important demographical components is the young adulthood phases. The early stages of young adulthood display a higher tendency to prefer more-crowded and popular GM areas. Especially the unconstructed semiopen/open sitting areas of cafes are prefered in this stage:

"Usually the space (GM) is very crowded, so there is a very lively environment. It is a very nice place to chat. I would define it somewhat alive, the energy is appealing to me. That's why (I spend time there), I suppose." (Participant19 - P19).

Even though a direct link has not been detected between GM formation and gender, the majority of the female participants have children and spend time on the play-grounds (constructed GM type with specific features for children). Moreover women with children tend to spend personal/ private time without their children; in that case they prefer unconstructed GM areas such as benches in front of the kiosks or small open-air terrace-like circulation spaces in the apartmen blocks. Findings show that flexible work patterns support more time to be spent in the unconstructed GM areas for mothers where they could also eat and drink and work while taking some personal time.

Marital status is closely related to GM area formation, married participants state that they mostly spend time in the unconstructed $\mathrm{GM}$, on benches on a regular spot, in small shared green spaces in order to "take some air" in short intervals. Single subjects also prefer unconstructed GM such as sitting areas of cafes on the sidewalks nevertheless they spend almost their whole spare time there unless they have "nothing better to do". They perceive these spaces as an extension to their living rooms:

"I see it (as a part of home), (I sit there) until the evening all through the day, and I return home and go to bed, that's all." (P02)

\section{Daily Living Culture}

Daily living culture is a very broad area with various components. These components basically reflect the essentials of daily living. Smoking habits, drinking frequency, coffee/ tea consumption and the interaction with the friends/relatives/parents/neighbours are the main subject matters. Moreover; daily living culture refer to life-style and the life-style tendencies indicate certain group memberships or coherences. ${ }^{40}$ The group coherence is quite discernible at trendy neighbourhoods (e.g. Galata, Cihangir or Maslak). For instance Cihangir display strong membership bonds. ${ }^{41}$ Considering the constructed/unconstructed GM types, the choices in life are primal. A subject from Cihangir quarter states:

"...compared to - for instance Beşiktaş district, the tenants are homogenous, perhaps because of the renting rates, location derive certain people to here. I think families with children do not exist here, because of steep roads, lacking parks or gardens. Younger people who can live in smaller spaces, stay closer to centre of life and afford to live here. It is not cheap at all. ... That's why it is homogenous. ... For instance in the apartment block I live, the entire tenants are young, white-collared, single. The whole block full of similar types. ..." (P36)

The same subject states that he prefers the open-air stairs connecting the lower neighbourhood as GM area; an unconstructed GM form. In such cases, a common vertical circulation element or a green area besides the building block is turned into a GM due to the its location with a seaview or a few trees. In such unconstructed GM areas; the physical comfort is mostly "neglected" by the users (Fig. 3, Fig. 4and Fig. 5):

"I do not consider the comfort. Only that I am appealed to the greenery, I sit there. ..." (P24)

Despite non smokers are more than the smokers in the sample (60\%), the findings point out preferences linked with smoking. There is evidence that local cafes with semi-open/open areas are turned into unconstructed GM areas due to smoking. Moreover, coffee/tea consumption was not taken as a subject matter in the questionaires; nevertheless in-depth interviews show a strong impact on unconstructed GM area formation along with smoking:

"As I said, I like drinking coffee very much. And most of my friends smoke, when I go there with them; it is appeal-

\footnotetext{
${ }^{40}$ Heijs et al., 2009, p. 348. ${ }^{41}$ Oztel-Agsakalli and Zeren-Gulersoy, 2015, p. 91.
} 


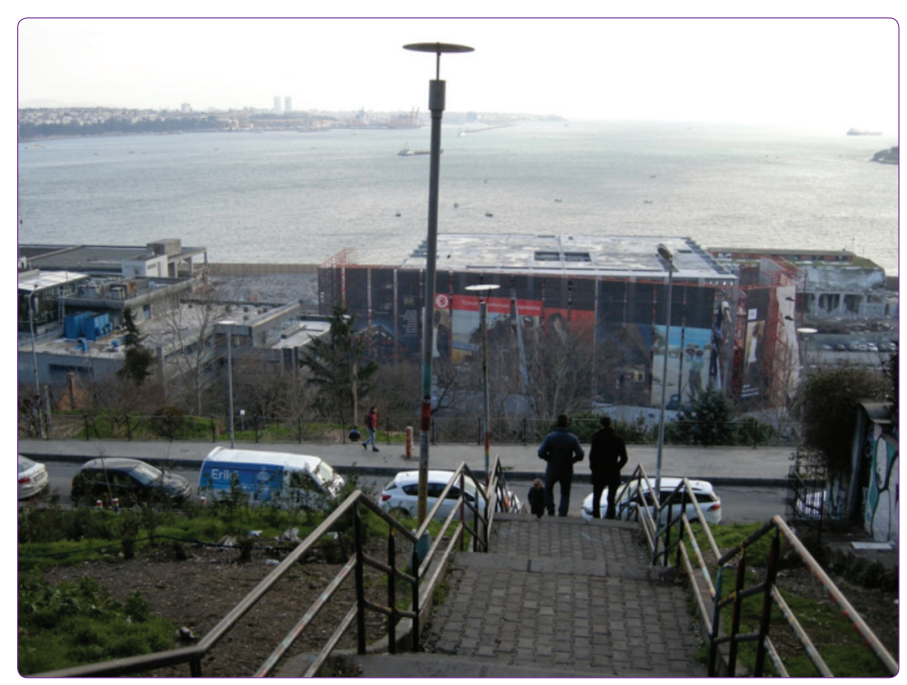

Figure 3. Cihangir, Roma Stairs, Beyoğlu.

ing to me as well as to them since there is open space for smoking. That's why I prefer there." (P19)

Family background is another prominent driver for un-

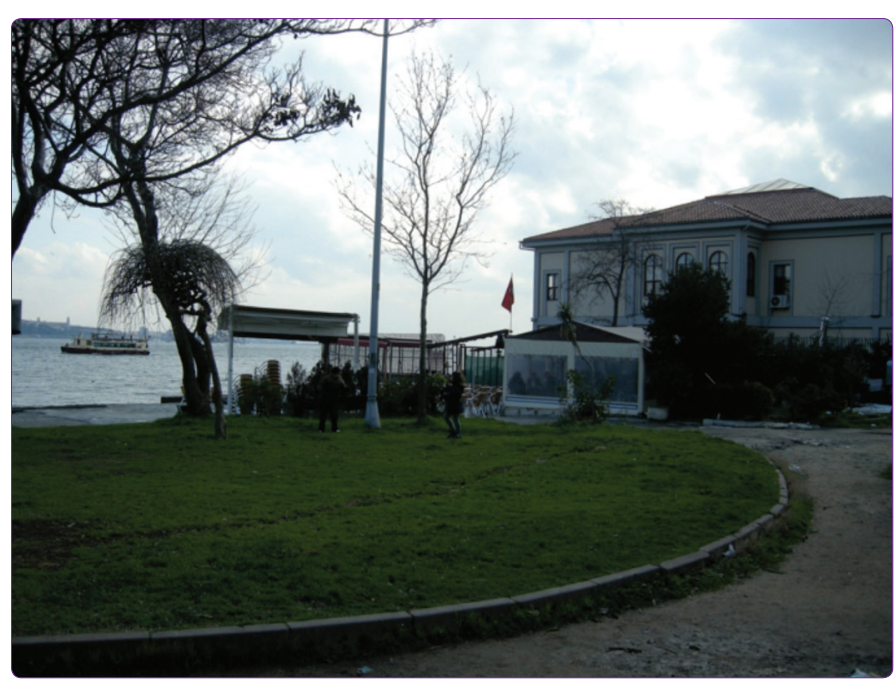

Figure 4. Findikli Park, Galata, Beyoğlu.

constructed GM usage. The habits of the adolacence years redirect future preferences. One subject addresses the unconstructed GM usage on the Bosphorus sea-fronts close

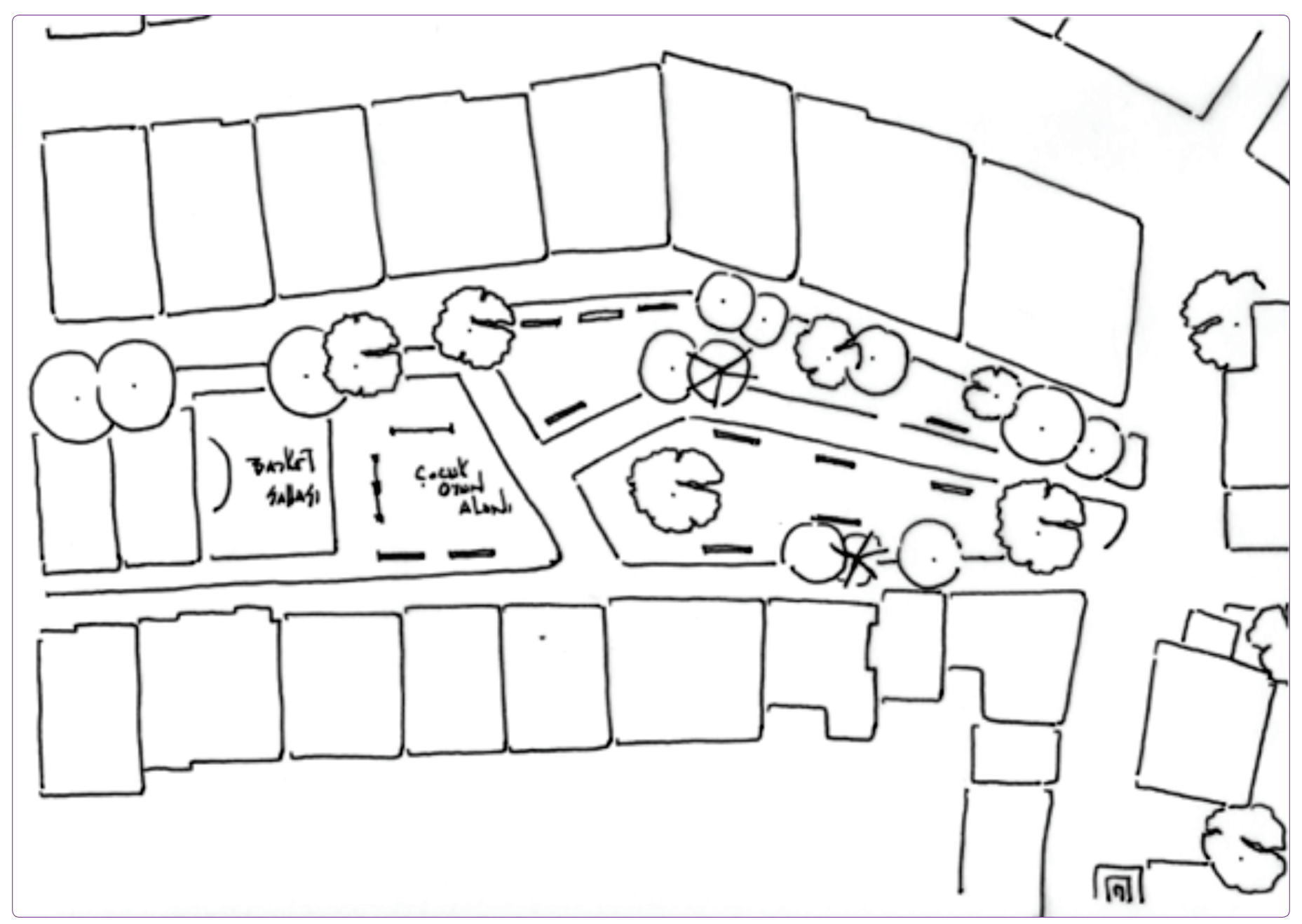

Figure 5. Misirlibahce Park, Beşiktaş, sketch by the author. 


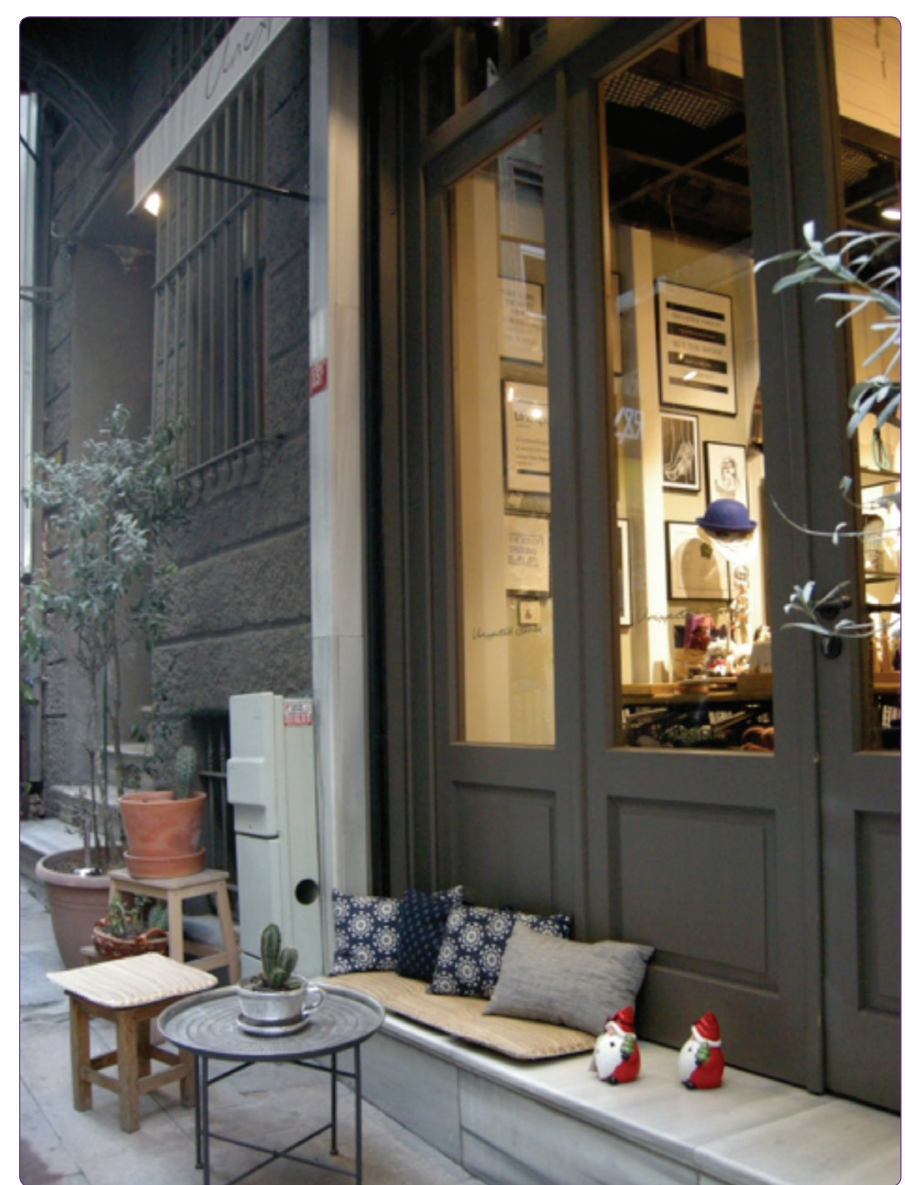

Figure 6. Entrance of a coffe shop, Galata, Beyoğlu.

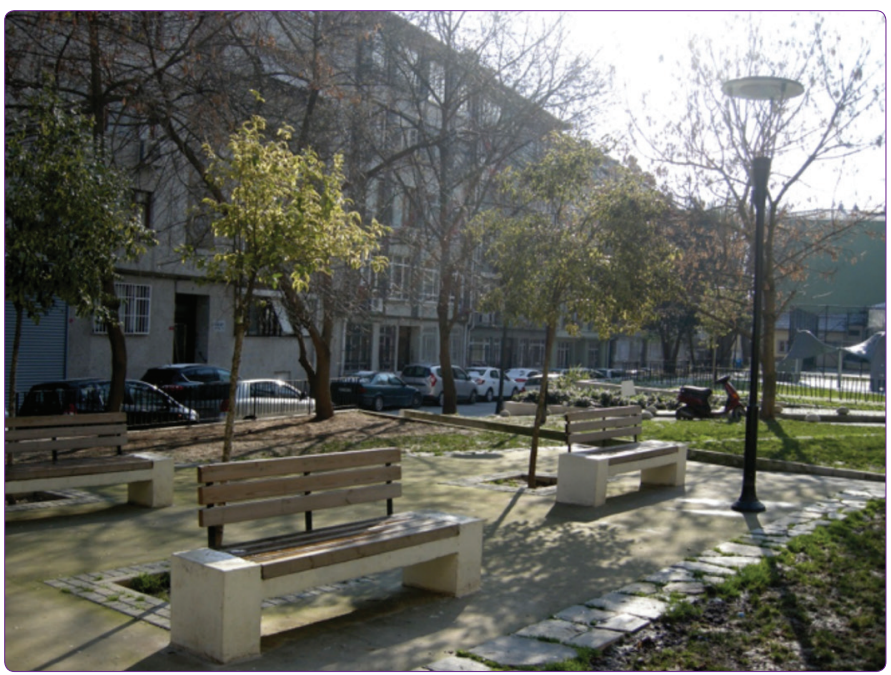

Figure 7. Misirlibahce Park, Beşiktaş.

to Cihangir-Galata neighbourhood. Another subject refers to his childhood years in a house with a garden:

"(My family background is relevant to GM my preference) because I was born and raised in another sea-front district, Uskudar. I am accustomed to the sea-side. Very accustomed to the Bosphorus. I had been going to the university by travelling across Bosphorus for years. It is im- possible for me to live somewhere without Bosphorus. ..." (P14) (Fig. 6).

"(My family background is relevant to GM preference) because I am familiar with the garden life. ... And even if it is between two apartment blocks (a small sitting niche), a place like this pleases me." (P23) (Fig. 7).

Social interaction in the residential area is related to the daily living patterns of the dwellers. Some interviews display a higher demand for social interaction in the vicinity of their dwellings while others do not signify close relationships as suggested in the definitions of life forms by Chicago School of Urban Research ${ }^{42}$ (life forms: particular group behaviour in the society). The interaction is not necessarily with the neighbours; but with the friends or families living in the walking distance..$^{43}$ Thus soft possession is developed:

"We see it (GM) as a part of our house. It does not belong to us but we see it as if it is ours." (P26)

Moreover, the unconstructed GM areas are prone to be parts of the houses due to their accesible locations:

"I see (GM as an extension to my house) ... Because every time I wake up, I see it. I work across to it." (P25)

The major motivation for preference is the easy-toaccess location. It is also the case for housing demands. Even though the residential preferences are not directly connected to the GM interaction potentials, residents experience strong ties with the community and possibilities to spend time in the residential area:

"Actually I chose (my house) because of its location. ... (the cultural/social possibilities) did not effect, I discovered (them) after moving to here." (K06)

The types of activities are also crucial; parallel with Cuba and Hummon ${ }^{44}$ suggesting the term at-homeness due to existance, affiliations and locus. The unconstructed GM areas cannot offer activity diversity:

"There is no possibility for variation of activities. The only thing we do is to chat, take some air, drink a cup of coffee. That's it." (P41)

However, constructed GM areas offer wider possibilities since they are designed particularly for common usage. For instance a participant states they "dried home-made pasta, celebrated a pre-marriage celebration and orginised a lot of bithday parties" on a terrace at the top of an apartment block, designed for such common activities (a constructed GM type).

\subsection{Physical features}

It is evident that very large spaces are not prefered by the sample as GM areas. Size and form of the space is very

\footnotetext{
42 Heijs et al., 2009, p. 349.

${ }^{44}$ Cuba and Hummon, 1993, p. 114.
} 
important; a sense of coziness to enhance social interaction for the unconstructed formation is sought for the majority of the subjects:

"... The space (GM area) is already large enough for me and my friend to sit together with other people around. (This size is) Very beneficial socially." (P23)

The climate aspect is also explored in terms of GM area formation categories. The climate tend to change as the location of the district is higher in terms of topography. For instance the sample from Maslak District mention that the wind is strong and colder than the districts on the sea-level which diminishes the time spent in the GM area.

Moreover some districts and quarters are regarded as unique and nice that refers to the indefinite ingredients ${ }^{45}$ in terms of impressions taken from a space:

“... in terms of socio-cultural layer ... I do not consider the open-air space as Fındıklı (a small park with a few very moderate kiosks serving tea/coffee with chairs and tables) ... It is rather a part of Cihangir because it is very close. ... I perceive them as a whole quarter together. Until Karakoy, the similar character is maintained, ..."

The urban morphology plays a crucial role for especially the unconstructed GM area formation. The main routes of the city are combinations of old districts with attached apartment blocks where parking is a major problem. So mostly very small gardens either turned into parking lots, rented by commercial bodies or closed by private users. "Green spaces owned by the apartment blocks or gardens do not exist at all" for the entire community. The sidewalks are very narrow due to the older urban tissue, where the main entrances of the building blocks open directly to these sidewalks. So it is very difficult to find a hierarchy in public/private usage; that the sidewalk becomes a new type of semi-public domain:

"Because we live in the city-centre, there is no garden or such, only the flat, so these spaces (GM areas are refered) are cafes on the sidewalks..." (P11)

Daily living culture affects perceptions towards constructed and unconstructed GM areas. The house sharing patterns refer to variations in $\mathrm{GM}$ area perceptions. It can be assumed that single young adults use GM areas for social interaction motivations. In this case some particular components are demanded in the GM; such as coffee/tea drinking and sitting. So they mostly prefer unconstructed GM areas. On the other hand young adults that share their dwellings with partners, family members or siblings tend to use GM areas due to activities such as exercising, having fresh air, spending time with children. In this case mostly constructed GM areas are prefered since such activities seek for suitable design.

\footnotetext{
${ }^{45}$ Heijs et al., 2009, p. 350.
}

The daily living culture notion is related to the family background and the profession of individuals. For instance the profession determines work patterns. Working shifts or home-office working refer to the time and period spent in the GM area. Moreover location of work and the working area (office, factory/production, open space, site) indicate the demands for GM areas in the young adults' lives. Also the pattern of home usage including cooking at home or staying home for only sleeping/resting) change the GM area intensities. Following the popular living trends (eating/drinking/entertainment, sports, weekday/weekend spare time spending, sleeping hours) modify the GM usage and its formation categories.

The general belief states that the public venues are declining in the urban areas. ${ }^{46}$ Worpole \& Knox ${ }^{47}$ claims the contrary that communal space expands in other ways. The unconstructed and constructed GM areas refer to such expansions. Nevertheless venues for outdoor activities, residential social interaction areas are still limited in Istanbul. The traditional neighbourhood patterns are diminishing; parallel to the some research displaying that the notion of neighbourhood interactions does not play a major role in many people's lives. ${ }^{48}$ Social interaction continues even if it is not necessarily the next door neighbours that young adults interact with. This is parallel to the literature stating that after full time university education, young adults seek for similar intellectual and social interaction in their residential circles. ${ }^{49}$

The notion of GM transforms with respect to changing daily living cultures. Habraken ${ }^{50}$ suggests that usage of built form stands for control on transformation of spaces. So, the distinction between the designer and user disappears. User also becomes the designer in this context. Habraken also states that the physical order is a level for integrations for users and designers; moreover through the territorial order, the territory and form interpret and define each other.

\section{Conclusion}

The contemporary perception reflects that the GM area formations vary by parameters of demography and daily living culture; as well as physical characteristics in the dense urban pattern. The unique features of GM areas such as positioning towards the view, location besides the sea or protection elements from unpleasant weather conditions provide possibilities for unconstruted GM constitution.

\footnotetext{
${ }^{46}$ Livesey, 2007, p. 1.

mark, 2003, p. 535.

${ }^{47}$ Worpole \& Knox, $2007 . \quad \quad{ }^{49}$ Gans, 1961, p. 177; Sampson, 1988,

${ }^{48}$ Blokland \& van Eijk 2010, p. 316; p. 771, Blockland \& van-Eijk, 2010, Joseph et al., 2007, p. 369-409; p.131-332; Levy \& Church, 2012, p. 3. Kleinhans, 2004, p. 382; Uiter- ${ }^{50}$ Habraken, 2000, p. 11.
} 
Young adults prefer to live in the central locations where social interaction and work opportunities are available. The roles of common spaces in the housing neighborhoods to support social interaction are significant. This social interaction does not necessarily reflect the pattern of traditional relations amongst neighbours. The young adults seek for their private space in the social connections and object to judgemental views towards their non-traditional living patterns. Even though they embrace the diversity, their preferences for dwelling areas reflect a level of homogeneity. They like being in a residential area that the most of the residents have similar tastes, life-styles and living practices with themselves. There is evidence that unconstructed GM areas play a crucial role in the neighbourhoods and create a sense of attachment in this regard. Some local spaces function as unconstructed GM with small kiosks selling coffee and tea, a few chairs, tables or benches on small green grounds. It should be noted that the constructed GM areas are used more effectively due to their more extensive activity possibilities.

The findings of this paper can be considered as a road map for future urban-shared-space designs. The new living tendencies urge for innovative planning in the housing settlements. It is obvious that the permability between different levels of private and public domains increase. This diverse typologies of semi-spaces also provide rich sets of social layers in the residential areas. The notions of constructed and unconstructed GM formulate locations of surprise, gatherings and further interaction; leading to healthier communities.

The study does not offer general suggestions but only contributes to the unique GM area formation types as a result of dense urban morphology. Further studies can be conducted for the young adults living in the periphery of Istanbul in order to make effective comparisons. Moreover, other age groups can be explored regarding the preferences of constructed/unconstructed GM areas.

\section{References}

Altman, I., Chemers, M. M. (1980). Territorial behaviour, Culture and Environment, California: University of Cambridge,120-153.

Bal, H. (2010). Bilimsel Araştırma Yöntemleri: Nicel Araştırma Yöntemi. Isparta: Fakülte.

Berngruber, A. (2015). 'Generation boomerang' in Germany? Returning to parental home in young adulthood. Journal of Youth Studies. 18(10), 1274-1290

Blokland, T., Van Eijk, G. (2010). Do People Who Like Diversity Practice Diversity in Neighbourhood Life? Neighbourhood Use and the Social Networks of 'Diversity Seekers' in a Mixed Neighbourhood in the Netherlands. Journal of Ethnic and Migration Studies. 36(2), 313-332.

Bourdieu, P. (1989). Social space and symbolic power. Sociological Theory. 7(1), 14-25.
Brown, H. J. (1975). Changes in workplace and residential locations. Journal of American Institute of Planners. 41(1), 32-39.

Carr, S., Francis, M., Rivlin, L., Stone, A. (1992). Public Space. New York: Cambridge University Press.

Çelebi, N. (1994). Yorumlayıcı etkileşim: yöntem mi, teknik mi?. Araştirma Ankara Üniversitesi Dil ve Tarih-Coğrafya Fakültesi Felsefe Bölümü Dergisi. 15, 154-156.

Charmaz, K. (1983). The grounded theory method: an explication and interpretation. Contemporary Field Research. Boston: Little, Brown \& Co.

Cuba, L., Hummon, D. M. (1993). A place to call home: Identification with dwelling, community, and region. The Sociological Quarterly, Midwest Sociological Society. 34(1), 111-131.

Francis, M. (2011). Mixed life places, Companion to Urban Design (Ed. Tridib Banerjee \& Anastasia Loukaitou-Sideris), 33, 432-445.

Gans, H. J. (1961). The balanced community: homogeneity or heterogeneity in residential areas. Journal of the American Institute of Planners, 27(3), 176-184.

Gehl, J. (1986). "Soft edges" in residential streets. Scandinavian Housing and Planning Research. 3(2), 89-102.

Gehl, J. (1987). The Life between Buildings. New York : Van Nostrand Reinhold.

Gençoğlu, A. Y. (2014). Bir kavram ve kuram üretme stratejisi olarak temellendirilmiş kuram. Tarih Okulu Dergisi (TOD). 7(17), 681-700.

Giddens, A. (1991). 'Living in the World': Dilemmas of the Self, Modernity and Self-Identity: Self and Society in the Late Modern Age. Stanford, CA: Stanford University Press.

Glaser, B., Strauss, A. (1967). The Discovery of Grounded Theory. Chicago: Aldine.

Gorman-Murray, A. (2015). Twentysomethings and twentagers: subjectives, spaces and young men at home. Gender, Place \& Culture. 22(3), 422-439

Gouldner, A. (1979). The Future of the Intellectual and the Rise of the New Class. London, New York: Macmillan.

Habraken, N. J. (1998). The Structure of the Ordinary, Form and Control in the Built Environment (Ed. J. Teicher). New York: MIT Press.

Heijs, W., Carton, M., Smeets, J., Van Gemert, A. (2009). The labyrinth of life-styles, Journal of Housing and the Built Environment. 24(3), 347-356.

Hummon, D. M. (1990). Commonplaces: Community Ideology and Identity in American Culture. Albany: State University of New York Press.

Hunter, A. (1974). Symbolic Communities: The Persistance and Change of Chicago's Local Communities. Chicago: University of Chicago Press.

Jencks, C. (1993). Heteropolis: Los Angeles, the Riots and the Strange Beauty of Heteroarchitecture. London: Academy Editions.

Joseph, M. L., Chaskin, R. J., Webber, H. S. (2007). The theoretical basis for addressing poverty through mixed-income development. Urban Affairs Review. 42(3), 369-409.

Karsten, L. (2007). Housing as a way of life: towards an understanding of middle-class families' preference for an urban residential location. Housing Studies. 22(1), 83-97.

Kim, J.H., Pagliara, F., Preston, J. (2005). The Intention to Move 
and Residential Location Choice Behaviour. Urban Studies. 42 (9), 1621-36.

Kim, J. H. (2006). Amenity valuing differentiation in residential location choice among income groups: a stated preference approach. International Journal of Urban Sciences. 10(1), 4157.

Kleinhans, R. (2004). Social implications of housing diversification in urban renewal: a review of recent literature. Journal of Housing and Built Environment. 19, 367-390.

Knorr-Siedow, T. (2008). Towards new forms of social housing in Germany. Urban Research and Practice. 1(3), 319-323.

Lefebvre, H. (1968). Bir araştırmanın ve bazı bulguların takdimi, Modern Dünyada Gündelik Hayat, Istanbul: Metis.

Levy, S., Church, S. (2012). Opening doors and sitting on floors: Public events in private spaces: the (re)-appropriation of space through grassroots events in Halifax. the Journal for Undergraduate Ethnography, 2(1),1-8.

Livesey, G. (2007). Deleuze, Whitehead, the event, and the contemporary city. Paper presented at the conference 'Event \& Decision', Claremont Graduate University, USA.

Lopes, M., Cruz, S., Pinho, P. (2012). The changing publicness of urban spaces. Paper presented at EURAU 2012 - Public Space and the Contemporary City, Porto, Portugal.

Madanipour, A. (2003). Public and Private Spaces of the City. New York: Routledge.

Montgomery, J. (1998). Making a city: urbanity, vitality and urban design. Journal of Urban Design. 3(1), 93-116.

Ozcelik-Guney, S. (2014). Grey matters: the boundaries of open spaces in the housing settlements. Paper presented ENHR Conference, New Researchers' Colloquium, UK.

Oztel-Agsakalli, O., Zeren-Gulersoy, N. (2015). Changes of urban structure in the Cihangir neighbourhood: Some proposals for re-designing the area. ITU A|Z Journal. (12)1, 83-105.

Pagliara, F., Preston, J. Jae-Hong, K. (2003). An analysis of residential location choice behaviour in Oxfordshire, UK: a combined stated preference approach. International Review of Public Administration. 8(1), 103-114.
Payne, L. L., Mowen A. J., Orsega-Smith, E. (2002). An examination of park preferences and behaviours among urban residents: the role of residential location, race, and age. Leisure Sciences. 24(2), 181-198.

Punch, K. F. (2005). Introduction to Social Research: Quantitative and Qualitative Approaches. New York: Sage Publications.

Rapoport, A. (1969). House Form and Culture (Foundations of Cultural Geography Series). Englewood Cliffs: N.J. Prentice Hall.

Sampson, R. J. (1988). Local friendship ties and community attachment in mass society: a multilevel systemic model. American Social Review. 53(5), 766-779.

Scheerlinck, K. (2012). Depth Configurations and Privacy. Proximity, Permeability and Territorial Boundaries in Urban Projects. Revealing Privacy: Debating the Understandings of Privacy. Margherita Carucci (ed.). Frankfurt am Maine: Peter Lang.

Stegman, M. A. (1969). Accessibility Models and Residential Location. Journal of the American Institute of Planners. 35(1), 22-29.

Strauss, A., Corbin, J. (1990). Grounded theory research: procedures, canons and evaluative criteria. Qualitative Sociology. 13(1), 3-21.

Thorkild, A. (2006). Residential choice from a lifestyle perspective. Housing, Theory and Society. 23(2), 109-130.

Tschumi, B. (1983). Spaces and Events, The Discourse of Events. London: Architectural Association.

Uitermark, J. (2003). Social mixing and the management of disadvantaged neighbourhoods: the Dutch policy of urban restructuring revisited. Urban Studies. 40(3), 531-549.

Whitehead, A. N. (2004). The Concept of Nature. New York: Prometheus Books, Amherst.

Whyte, W. (2000). The social life of small urban spaces. Project for Public Spaces. New York.

Worpole, K., Knox, C. (2007), The Social Value of Public Spaces, York: Joseph Rowntree Foundation.

Yardım, N., Hacihasanoglu, O. (2015). Urban sections. ITU A|Z Journal. 12 (1), 37-51. 